Atıf İçin: Karaşahin M, 2021. Farklı Yetiştirme Ortamı, Altlık ve Sulama Yöntemi Uygulamalarının Topraksız Rulo Çim Üzerine Etkileri. Iğdır Üniversitesi Fen Bilimleri Enstitüsü Dergisi, 11(2): 1616-1624.

To Cite: Karaşahin M, 2021. Effects of Different Growing Medium, Substrate and Irrigation Method Applications on Soilless Roll Sod. Journal of the Institute of Science and Technology, 11(2): 1616-1624.

\title{
Effects of Different Growing Medium, Substrate and Irrigation Method Applications on Soilless Roll Sod
}

\section{Muhammet KARAŞAHIN ${ }^{1 *}$}

\begin{abstract}
This research was carried out in the hydroponics production field at Selcuk University, Cumra School of Applied Sciences between the dates of 01.09.2019 and 28.02.2020. This study was conducted in order to determine the effects of different growing medium (Co: control, Wp: wood powder, Pe: perlite, and Tu: turf (cocopeat)), substrates (Cf: cotton fiber, Pf: polyester fiber, Pm: polyester mesh), and irrigation method (Sp: sprinkler, Ti: tidal, and Fp: fogponic) applications on soilless roll sod, the following characteristics were examined: fresh grass yield $\left(\mathrm{g} \mathrm{m}^{2-1}\right)$, dry matter rate $(\%)$, dry grass yield $\left(\mathrm{g} \mathrm{m}^{2-1}\right)$, plant height $(\mathrm{mm})$, emergence speed (day), covering speed (day), root length (cm), overall appearance (1-9), shoot diameter ( $\mathrm{mm})$, tiller number (number $\mathrm{cm}^{2-1}$ ), leaf blade length $(\mathrm{cm})$, leaf blade width (mm) and the index value (leaf blade length/leaf blade width). It was observed that there was no statistical difference between the applications in terms of overall appearance values. When root length and tiller number values, which are among the important growth parameters in the soilless roll sod production, application conveniences, biodegradability, and production costs are considered together, "Tu" growing medium, "Cf" substrate and "Sp" irrigation method applications came to the fore. To be able to obtain more realistic recommendations on this issue, land applications should be included in future research.
\end{abstract}

Keywords: Growing medium, irrigation method, roll sod, substrate

\section{Farklı Yetiştirme Ortamı, Altlık ve Sulama Yöntemi Uygulamalarının Topraksız Rulo Çim Üzerine Etkileri}

ÖZET: Araştırma, 01.09.2019 ile 28.02.2020 tarihleri arasında, Selçuk Üniversitesi Çumra Uygulamalı Bilimler Yüksekokulu hidroponik üretim alanında yürütülmüştür. Çalışma, farklı yetiştirme ortamı (Co; kontrol, Wp; odun tozu, Pe; perlit ve Tu; torf (cocopeat)), altlık (Cf; pamuk elyaf, Pf; polyester elyaf ve Pm; polyester elek) ve sulama yöntemi (Sp; yağmurlama, Ti; gel-git ve Fp; fogponik) uygulamalarının topraksız rulo çim üzerine etkilerini belirlemek amacıyla yürütülmüş ve yeşil ot verimi $\left(\mathrm{g} \mathrm{m}^{2-1}\right)$, kuru madde oranı $(\%)$, kuru ot verimi $\left(\mathrm{g} \mathrm{m}^{2}-1\right)$, bitki boyu (mm), çıkış hızı (gün), kaplama hızı (gün), kök uzunluğu (cm), genel görünüm (1-9), sürgün çapı (mm), kardeş sayısı (adet $\mathrm{cm}^{2-1}$ ), yaprak ayası uzunluğu (cm), yaprak ayası genişliği $(\mathrm{mm})$ ile indeks değeri (Yaprak ayası uzunluğu/Yaprak ayası genişliği) özellikleri incelenmiştir. Genel görünüm değerleri bakımından uygulamalar arasında istatistiki farklılığın olmadığ1 görülmüştür. Topraksız rulo çim üretiminde önemli gelişim parametrelerinden kök uzunluğu ve kardeş sayısı değerleri uygulama kolaylıkları, biyo çözünürlük ve üretim maliyetleri birlikte dikkate alınarak değerlendirildiğinde Tu yetiştirme ortamı, Cf altlık ve Sp sulama yöntemi uygulamaları ön plana çıkmaktadır. Bu konuda daha gerçekçi tavsiyeler için ileride yapılacak araştırmalara arazi uygulamaları dahil edilmelidir.

Anahtar Kelimeler: Altlık, rulo çim, sulama yöntemi, yetiştirme ortamı

\footnotetext{
${ }^{1}$ Muhammet KARAŞAHIN (Orcid ID: 0000-0001-8586-0701), Selçuk Üniversitesi, Çumra Uygulamalı Bilimler Yüksekokulu, Organik Tarım İşletmeciliği Bölümü, Çumra, Konya, Türkiye

*Sorumlu Yazar/Corresponding Author: Muhammet KARAŞAHIN, e-mail: mkarasahin@ selcuk.edu.tr
} 


\section{INTRODUCTION}

Grass areas are very useful in aesthetically beautifying the environment, changing the climate, and improving air quality. Grasses are the only landscape plant that can be used in areas where there is intense mobility. Grass plants have the characteristics of regrowth after chewing, plucking, and mowing processes. Grass fields are taking place among the fire control strategies in urban areas, and they take on an important task in holding the waters formed by extreme rains and lost by surface runoff. In urban centers, they are used on the roofs and facades of buildings to reduce air pollution and improve air quality (Farid et al., 2016). The benefits of grass areas can be divided into three groups as functional, recreational, and aesthetic components (Beard and Green, 1994). Grass areas are not only important in an aesthetic sense but also they add value to settlements.

Roll sod is grass harvested from its place with roots and soil clinging to them to be grown elsewhere (Pessarakli, 2008). The use of roll sod can be a quick and simple solution to repair damages that occur frequently in sports fields; because there is very little time for rooting in such areas, thick-cut roll sods are often used (Pessarakli, 2008). Roll sod is traditionally produced in agricultural lands. The biggest pressure on sustainable roll sod production is the removal of the very precious top layer of agricultural land with each harvest. For sustainable roll grass production, the production of roll grass in greenhouses in soilless environments comes across as alternative growing techniques by preventing soil losses, shortening cultivation time, and eliminating difficulties in roll sod harvesting. The use of renewable resources in production reduces costs, ensures waste management, and contributes to sustainable environmental management. For this purpose, the use of composted organic wastes as a growing material in the production of rolling sod would be a very environmental approach (Dede and Özdemir, 2011).

Sustainable agriculture is an agricultural system that minimizes waste and environmental impacts, while advising farmers to work with natural inputs to protect land and water resources (Mason, 2003). Today, most of the studies are aiming to increase the use of renewable resources. By using inorganic and organic materials mixtures and by increasing their water retention capacity, the negativities experienced in plant-feeding can be avoided (Albaho et al., 2009; Johnson, 2010; Gutierrez et al., 2012). A good growing medium should have the ability to protect and support the plant, have the ability to store enough water and plant nutrients, and provide opportunity for gas exchange between the roots and the atmosphere by providing adequate oxygen to the plant roots. Growing media have a variety of materials and structures that may have direct or indirect effects on plant growth and development. Materials such as turf, perlite, coconut fiber and mat, volcanic tuff, and compost can be used alone as growing media; additionally, their mixtures are also widely used as growing media (Gutierrez et al., 2012). In hydroponic growing systems, it is important to apply the right amount of water and plant nutrients to be able to prevent stress conditions and to keep production under control. In grass production, hydroponic systems are modern technologies that reduce the risks of weeds and disease. In the prevention of the negative effects of many diseases and pests originating from the soil, production in a controlled medium becomes important day by day. Also, the soilless culture system facilitates water and fertilizer management and increases the efficiency of their usage by plants (Savvas et al., 2013). Since grass species and varieties have different characteristics, they need different water and irrigation regime (Carrow, 1995). Whereas warm-climate grass species can be grown with less water supply, cool-climate grass species need more water and a more sensitive irrigation program for growth. The same grass species need different amounts of water when they are grown in different environmental conditions. 
Grass production on plastic in soilless environments has significant advantages over the traditional grass production (Roberts et al., 2001; Karaşahin, 2020). While the production of roll sod in soil by traditional methods requires considerable time and expense, the production of grass on plastic in a soilless medium can be done in a much shorter time and more efficiently (Decker and Decker, 1988). Ventilation, moisture, plant nutrients, and growing medium components play important roles in growth and optimum quality (Bruce et al., 2000; Brien and Barker, 1995). The use of turf as grass growing medium is quite costly, so it is important to find suitable alternatives for this purpose. Compared to traditional grass production, the production time of grass on plastic was able to be reduced from 2 years to 7-10 weeks for Festuca aurandinacea by the use of composts derived from organic waste (Decker, 2001). In the plant production in soilless media, more products can be obtained in less time, plants can be grown denser in the unit area, with a balanced supply of air, water, and plant nutrients, the products become more resistant to diseases, and natural or biological control can be performed easily. Moreover, soil-borne diseases and pests are not seen and there is no need to fight weeds (Munoz, 2010). Various materials such as saw powder, coconut fiber, sphagnum turf, rice husk, polyurethane, growing slabs, lava tuff are used as growing materials in hydroponic production. A good growing material should have high porosity, sufficient oxygen and water dispersal, low EC and $\mathrm{pH}$ values between 5 and 6.5 , and should be chemically inert and sterile (Yeager et al., 2007).

In this study, it was aimed to determine the effects of different growing medium, substrate, and irrigation method applications on soilless roll sod.

\section{MATERIALS AND METHODS}

The research was carried out in the hydroponics production field at Selcuk University, Cumra School of Applied Sciences between the dates of 01.09.2019 and 28.02.2020 (Figure 1). 33x11.5 cm twelve aluminum frames were used as the cultivation setting (Figure 2).

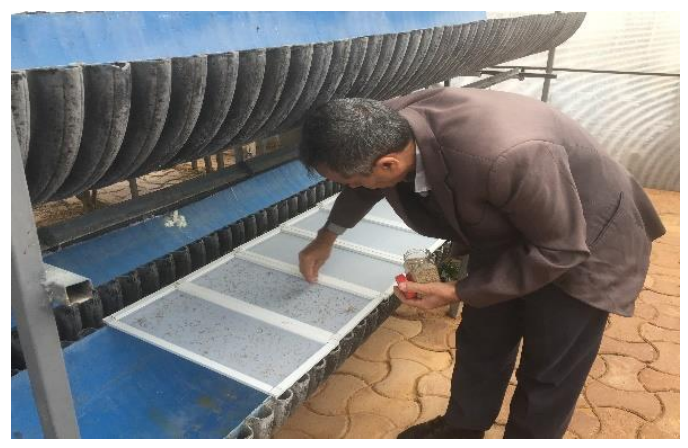

Figure 1. Hydroponic production field

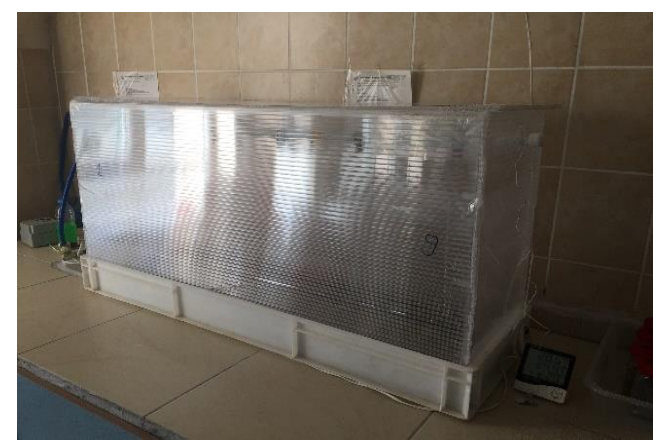

Figure 2. Cultivation setting

In the study, $50 \mathrm{~g} \mathrm{~m}^{-2}$ was applied as seed amount, $20{ }^{\circ} \mathrm{C}$ as ambient temperature, control as growing medium and fertilizer source, cotton fiber as the substrate material, sprinkler as irrigation method $\left(20 \sec 6 \mathrm{~h}^{-1}\right)$, and 15 days as cultivation duration. Only the parameters investigated have been changed in each application. In the irrigation system, the city water supply network was used as the water source (Table 1). The costs of the growing medium vary according to the capacity.

In the research, perennial ryegrass (Lolium perenne L.) was used as plant material. In order to determine the effects of different growing medium (Co: control, Wp: wood powder, Pe: perlite, and Tu: turf (cocopeat)), substrates (Cf: cotton fiber, Pf: polyester fiber, Pm: polyester mesh), 
and irrigation method (Sp: sprinkler, Ti: tidal, and Fp: fogponic) applications on soilless roll sod, the following characteristics were examined: fresh grass yield $\left(\mathrm{g} \mathrm{m}^{2}-1\right)$, dry matter rate $(\%)$, dry grass yield $\left(\mathrm{g} \mathrm{m}^{2}-1\right)$, plant height $(\mathrm{mm})$, emergence speed (day), covering speed (day), root length $(\mathrm{cm})$, overall appearance (1-9), shoot diameter ( $\mathrm{mm}$ ), tiller number (number $\mathrm{cm}^{2-1}$ ), leaf blade length $(\mathrm{cm})$, leaf blade width (mm) and the index value (leaf blade length/leaf blade width).

Table 1. Properties of the irrigation water

\begin{tabular}{llll}
\hline \multicolumn{1}{c}{ Specifications $\left(\mathbf{m g ~ l}^{-\mathbf{1}}\right)$} & \multicolumn{2}{c}{ Specifications $\left(\mathbf{m g ~ l}^{\mathbf{- 1}}\right)$} \\
\hline $\mathrm{pH}$ & 7.19 & $\mathrm{Zn}$ & 0.94 \\
$\mathrm{EC}\left(\mathrm{mS} \mathrm{cm}^{-1}\right)$ & 0.615 & $\mathrm{P}$ & 0.20 \\
$\mathrm{NO}_{3}\left(\mathrm{mg} \mathrm{l}^{-1}\right)$ & 3.22 & $\mathrm{~K}$ & 0.03 \\
$\mathrm{Ca}\left(\mathrm{mg} \mathrm{l}^{-1}\right)$ & 150.12 & $\mathrm{~B}$ & 0.13 \\
$\mathrm{Mg}\left(\mathrm{mg} \mathrm{l}^{-1}\right)$ & 10.7 & $\mathrm{Mn}$ & 0.02 \\
$\mathrm{Na}\left(\mathrm{mg} \mathrm{l}^{-1}\right)$ & 2.93 & $\mathrm{Cu}$ & 0.02 \\
\hline
\end{tabular}

As different irrigation methods, sprinkler irrigation (irrigation in the form of droplets from the top via nozzles), tidal irrigation (filling up to a certain level with water and emptying), and fogponic irrigation (irrigation with water atomized into cold vapor by ultrasonic nozzle) were applied. In the system that can be controlled by the microprocessor, irrigation time and amount were set with the coupled electro valve (Figures 3, 4, and 5).

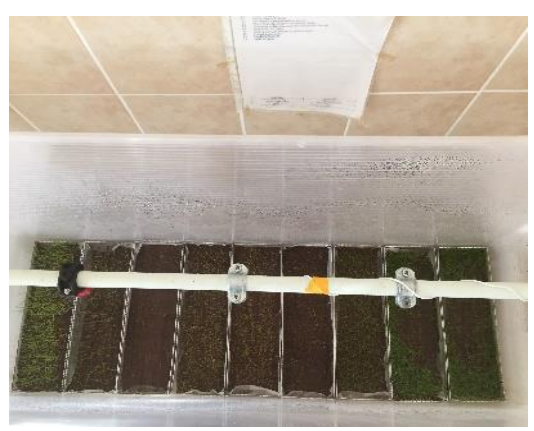

Figure 3. Sprinkler irrigation method

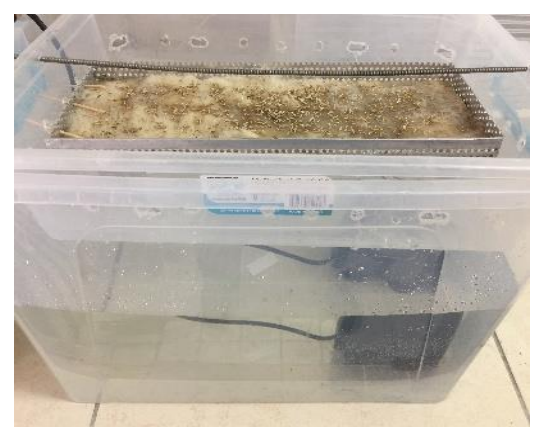

Figure 4. Tidal irrigation method

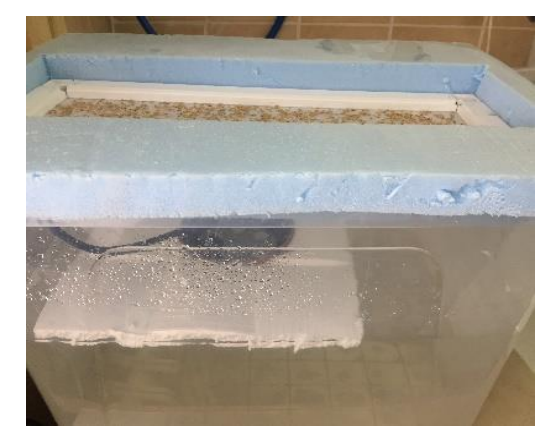

Figure 5. Fogponic irrigation method

The trials were conducted as three replications according to the randomized plots experimental design. The results were subjected to the variance analysis and differences were determined by using the $\mathrm{F}$ test. The average values of the processes whose differences were determined were grouped according to the "HSD" significance test (JMP, 2007).

\section{RESULTS AND DISCUSSION}

\section{Growth Parameters of Different Growing Medium Applications}

The highest fresh grass yield values were obtained from Co, Wp, and Tu applications $(377.5,421.6$ and $395.2 \mathrm{~g} \mathrm{~m}^{2-1}$, respectively), and they took place in the same statistical group (a). The lowest (316.2 $\left.\mathrm{g} \mathrm{m}^{2-1}\right)$ values were obtained from Pe applications $(\mathrm{P}<0.01)$. The highest dry matter rate and dry grass 
yield values were obtained from Co applications ( 8.8 and $33.2 \mathrm{~g} \mathrm{~m}^{2-1}, \mathrm{P}<0.05$ and $\mathrm{P}<0.01$, respectively). The lowest dry matter rate values were obtained from $\mathrm{Pe}$ and $\mathrm{Wp}$ applications (8.4 and 7.5\%, respectively), and they were in the same statistical group (b). The lowest dry grass yield values (26.61 $\mathrm{g}$ $\left.\mathrm{m}^{2-1}\right)$ were obtained from Pe applications $(\mathrm{P}<0.01)$. The highest $(4.5 \mathrm{~cm})$ root length values were obtained from $\mathrm{Tu}$ applications, while the lowest values were obtained from the Pe and $\mathrm{Wp}$ applications, and they took place in the same statistical group (c) $(1.0$ and $1.0 \mathrm{~cm}$, respectively, $\mathrm{p}<0.01)$. There was no statistically significant difference between different growing medium applications in terms of plant height, emergence, and covering speed values (Table 2).

Table 2. Fresh grass yield, dry matter rate, dry grass yield, plant height, emergence and covering speed, root length values for different growing media

\begin{tabular}{|c|c|c|c|c|c|c|c|c|}
\hline \multicolumn{2}{|c|}{ Applications } & $\begin{array}{c}\text { Fresh Grass } \\
\text { Yield } \\
\left(\mathrm{g} \mathrm{m}^{-2}\right)\end{array}$ & $\begin{array}{c}\text { Dry Matter } \\
\text { Rate } \\
(\%)\end{array}$ & $\begin{array}{c}\text { Dry Grass } \\
\text { Yield } \\
\left(\mathrm{g} \mathrm{m}^{-2}\right)\end{array}$ & $\begin{array}{c}\text { Plant } \\
\text { Height } \\
\text { (cm) }\end{array}$ & $\begin{array}{c}\text { Emergence } \\
\text { Speed } \\
\text { (day) }\end{array}$ & $\begin{array}{c}\text { Covering } \\
\text { Speed } \\
(\text { day })\end{array}$ & $\begin{array}{c}\text { Root } \\
\text { Length } \\
\text { (cm) }\end{array}$ \\
\hline \multirow{4}{*}{$\begin{array}{l}\text { Growing } \\
\text { Medium }\end{array}$} & Co & $377.5 \mathrm{a}$ & $8.8 \mathrm{a}$ & $33.20 \mathrm{a}$ & 8.6 & 5 & 7 & $3.5 \mathrm{~b}$ \\
\hline & $\mathbf{P e}$ & $316.2 \mathrm{~b}$ & $8.4 \mathrm{~b}$ & $26.61 \mathrm{c}$ & 6.8 & 5 & 7 & $1.0 \mathrm{c}$ \\
\hline & Wp & $421.6 \mathrm{a}$ & $7.5 \mathrm{~b}$ & $31.62 \mathrm{~b}$ & 9.0 & 5 & 7 & $1.0 \mathrm{c}$ \\
\hline & $\mathbf{T u}$ & $395.2 \mathrm{a}$ & $8.1 \mathrm{ab}$ & $32.14 \mathrm{ab}$ & 10.1 & 5 & 7 & $4.5 \mathrm{a}$ \\
\hline HSI & & $35.07 * *$ & $0.07 *$ & $0.06 * *$ & Ns & Ns & Ns & $0.46^{* *}$ \\
\hline
\end{tabular}

HSD; Honesty Significant Difference, *; P <0.05, **; P <0.01, Ns; Not significant

Whereas the highest $(0.56 \mathrm{~mm})$ shoot diameter values were obtained from $\mathrm{Wp}$ applications, the lowest $(0.45 \mathrm{~mm})$ values were obtained from Pe applications $(\mathrm{P}<0.01)$. The highest tiller number values were obtained from $\mathrm{Wp}$ and $\mathrm{Tu}$ applications (944.3 and 888.8 number $\mathrm{cm}^{2}{ }^{-1}$, respectively), and they were in the same statistical group (a). On the other hand, the lowest $\left(733.2\right.$ number $\left.\mathrm{cm}^{2}{ }^{-1}\right)$ values were obtained from $\mathrm{Pe}$ applications $(\mathrm{P}<0.01)$. The highest leaf blade width values were obtained from Co and Wp applications (1.06 and $1.01 \mathrm{~mm}$, respectively) and they were in the same statistical group (a). The lowest values, on the other hand, were obtained from $\mathrm{Pe}$ and $\mathrm{Tu}$ applications $(0.81$ and $0.86 \mathrm{~mm}$, respectively, $\mathrm{p}<0.01)$ and they were in the same statistical group (b). There was no statistically difference between different growing medium applications in terms of overall appearance, leaf length, and index values (Table 3 ).

Table 3. Overall appearance, shoot diameter, tiller number, leaf blade length, leaf blade width, and index values belonging to different growing mediums

\begin{tabular}{cccccccc}
\hline Applications & $\begin{array}{c}\text { Overall } \\
\text { Appearance } \\
(\mathbf{1 - 9})\end{array}$ & $\begin{array}{c}\text { Shoot } \\
\text { Diameter } \\
(\mathbf{m m})\end{array}$ & $\begin{array}{c}\text { Tiller } \\
\text { Number } \\
\left(\text { number } \mathbf{c m}^{-2}\right)\end{array}$ & $\begin{array}{c}\text { Leaf Blade } \\
\text { Length } \\
(\mathbf{c m})\end{array}$ & $\begin{array}{c}\text { Leaf Blade } \\
\text { Width } \\
(\mathbf{m m})\end{array}$ & $\begin{array}{c}\text { Index } \\
\text { Values }\end{array}$ \\
\hline \multirow{2}{*}{ Growing } & $\mathbf{P e}$ & 9 & $0.51 \mathrm{~b}$ & $833.2 \mathrm{ab}$ & 6.3 & $1.06 \mathrm{a}$ & 59.6 \\
Medium & $\mathbf{W p}$ & 9 & $0.45 \mathrm{c}$ & $733.2 \mathrm{~b}$ & 5.8 & $0.81 \mathrm{~b}$ & 71.4 \\
& $\mathbf{T u}$ & 9 & $0.56 \mathrm{a}$ & $944.3 \mathrm{a}$ & 7.5 & $1.01 \mathrm{a}$ & 73.8 \\
\hline HSD & & $\mathrm{Ns}$ & $0.50 \mathrm{~b}$ & $888.8 \mathrm{a}$ & 8.1 & $0.86 \mathrm{~b}$ & 94.4 \\
\hline
\end{tabular}

HSD; Honesty Significant Difference, *; P <0.05, **; P <0.01, Ns; Not significant

In their study conducted to determine the optimal covering material for ecomat material, Sorochan and Rogers (1995), examined germination rate, coating rate, and growth rate by using seven different materials (germinator, penn mulch, paper mulch, rubber clippings, natural clay-loam soil, straw, and very thin turf). They found that the fastest germination occurred 7 days after the sowing in the application 
where ryegrass and penn mulch were used as cover material. In his study conducted in the United Arab Emirates, by germinating bermuda grass and paspalum grass seeds in different media (rock wool, jute, and rock wool together with jute), Hussain (2017), investigated the effects of these media on soilless grass production. He noted that the highest plant biomass was obtained from bermudagrass and from the applications in which the combination of rock wool and jute as well as only rock wool is used.

\section{Growth Parameters of Different Substrate Applications}

It was observed that the effects of different substrate applications on fresh grass yield, dry matter rate, dry grass yield, plant height, emergence, covering rate, and root length values were not statistically significant (Table 4).

Table 4. Fresh grass yield, dry matter rate, dry grass yield, plant height, emergence, and covering rate values of different substrates

\begin{tabular}{ccccccccc}
\hline \multicolumn{2}{c}{ Applications } & $\begin{array}{c}\text { Fresh Grass } \\
\text { Yield } \\
\left(\mathbf{g ~ m ~ m}^{-2}\right)\end{array}$ & $\begin{array}{c}\text { Dry Matter } \\
\text { Rate } \\
(\mathbf{\%})\end{array}$ & $\begin{array}{c}\text { Dry Grass } \\
\text { Yield } \\
\left(\mathbf{g ~ m ~ m}^{-2}\right)\end{array}$ & $\begin{array}{c}\text { Plant } \\
\text { Height } \\
(\mathbf{c m})\end{array}$ & $\begin{array}{c}\text { Emergence } \\
\text { Speed } \\
(\mathbf{d a y})\end{array}$ & $\begin{array}{c}\text { Covering } \\
\text { Speed } \\
(\mathbf{d a y})\end{array}$ & $\begin{array}{c}\text { Root } \\
\text { Length } \\
(\mathbf{c m})\end{array}$ \\
\hline \multirow{2}{*}{ Substrates } & Cf & 377.5 & 8.8 & 33.20 & 8.6 & 5 & 7 & 3.5 \\
& Pf & 384.1 & 8.8 & 33.99 & 8.6 & 5 & 7 & 3.5 \\
& Pm & 412.3 & 8.1 & 33.72 & 8.6 & 5 & 7 & 3.5 \\
\hline \multicolumn{2}{c}{ HSD } & Ns & Ns & Ns & Ns & Ns & Ns & Ns \\
\hline
\end{tabular}

HSD; Honesty Significant Difference, *; P <0.05, **; P <0.01, Ns; Not significant

Whereas the highest shoot diameter and tiller number values were obtained from Pf applications ( $0.55 \mathrm{~mm}$ and 944.3 number $\mathrm{cm}^{2-1}$, respectively), the lowest values were obtained from Pm applications $\left(0.45 \mathrm{~mm}\right.$ and 666.6 number $\mathrm{cm}^{2-1}$, respectively, $\left.\mathrm{p}<0.01\right)$. The highest leaf blade width values were obtained from Cf and Pf applications (1.06 and $0.96 \mathrm{~mm}$, respectively), and they took place in the same statistical group (a). The lowest $(0.80 \mathrm{~mm})$ values were obtained from Pm applications $(\mathrm{P}<0.01)$. The effects of different substrate applications on the overall outlook, leaf blade length, and index values were not statistically significant (Table 5).

Table 5. Overall appearance, shoot diameter, tiller number, leaf blade length, leaf blade width, and index values of different substrates

\begin{tabular}{ccccccccc}
\hline Applications & $\begin{array}{c}\text { Overall } \\
\text { Appearance } \\
(\mathbf{1 - 9})\end{array}$ & $\begin{array}{c}\text { Shoot } \\
\text { Diameter } \\
(\mathbf{m m})\end{array}$ & $\begin{array}{c}\text { Tiller } \\
\text { Number } \\
\left(\text { number } \mathbf{~ c m}^{-2}\right)\end{array}$ & $\begin{array}{c}\text { Leaf Blade } \\
\text { Length } \\
(\mathbf{c m})\end{array}$ & $\begin{array}{c}\text { Leaf Blade } \\
\text { Width } \\
(\mathbf{m m})\end{array}$ & $\begin{array}{c}\text { Index } \\
\text { Values }\end{array}$ \\
\hline \multirow{2}{*}{ Substrates } & Cf & 9 & $0.51 \mathrm{~b}$ & $833.2 \mathrm{~b}$ & 6.3 & $1.06 \mathrm{a}$ & 59.6 \\
& Pf & 9 & $0.55 \mathrm{a}$ & $944.3 \mathrm{a}$ & 6.6 & $0.96 \mathrm{a}$ & 68.9 \\
& Pm & 7 & $0.45 \mathrm{c}$ & $666.6 \mathrm{c}$ & 6.8 & $0.80 \mathrm{~b}$ & 85.4 \\
\hline \multicolumn{2}{c}{ HSD } & & $\mathrm{Ns}$ & $0.01 * *$ & $72.67 * *$ & $\mathrm{Ns}$ & $0.07 * *$ & $\mathrm{Ns}$ \\
\hline
\end{tabular}

HSD; Honesty Significant Difference, *; P <0.05, **; P <0.01, Ns; Not significant

By placing slow-release nutrients, herbicides, and pesticides in perforated synthetic fiber material, Anton (1993), mixed it with nonwoven organic carpet material and produced soilless roll sod from coolclimate grass mixture. He stated that the biodegradability times of substrate materials used in soilless roll sod production limited their use. In their research focusing on the production of soilless roll sod in which kenaf-based material knitted like mesh was used as a biodegradable substrate, Hensler et al. (1998), stated that with this technique, production could be made faster than field-based roll sod. In the 
productions of roll bermudagrass (Cynodon magenissii), Japanese grass (Zoysia japonica), centipedegrass (Eremochloa ophiuroides), which are performed in field conditions, a period of 3-12, 1218 and 12-15 months is needed; however, with this technique, the same varieties can become available for sale in 6,15 , and 10 weeks, respectively. In their later research, the same researchers made the system more economical by using a cheaper cotton-based substrate instead of a kenaf-based substrate (Hensler et al., 1998). In a joint study developed and patented by Mississippi State University (2006) and commercialized by the Phillip Jennings Turf company, the dream of soilless roll sod production was realized by germinating the rhizomes of bermudagrass on cotton felt in a greenhouse environment with the help of hydroponic solution, and it was patented. Thus, they noted that for sports areas and golf courses, they could produce grass that did not come into contact with any chemical pollution, such as herbicide and pesticide.

\section{Growth Parameters of Different Irrigation Methods}

The highest root length values $(4.1 \mathrm{~cm})$ were obtained from $\mathrm{Fp}$ applications, while the lowest values were obtained from $\mathrm{Sp}$ and $\mathrm{Ti}$ applications ( 3.5 and $3.5 \mathrm{~cm}$, respectively), and they took place in the same statistical group (b) $(\mathrm{P}<0.01)$. It was observed that the effects of different irrigation methods on fresh grass yield, dry matter rate, dry grass yield, plant height, emergence, and covering rate were not statistically significant (Table 6).

Table 6. Fresh grass yield, dry matter rate, dry grass yield, plant height, emergence and covering speed, root length values of different irrigation methods

\begin{tabular}{ccccccccc}
\hline Applications & $\begin{array}{c}\text { Fresh Grass } \\
\text { Yield } \\
\left(\mathbf{g ~ m}^{-2}\right)\end{array}$ & $\begin{array}{c}\text { Dry Matter } \\
\text { Rate } \\
(\mathbf{\%})\end{array}$ & $\begin{array}{c}\text { Dry Grass } \\
\text { Yield } \\
\left(\mathbf{g ~ m}^{-2}\right)\end{array}$ & $\begin{array}{c}\text { Plant } \\
\text { Height } \\
(\mathbf{c m})\end{array}$ & $\begin{array}{c}\text { Emergence } \\
\text { Speed } \\
(\mathbf{d a y})\end{array}$ & $\begin{array}{c}\text { Covering } \\
\text { Speed } \\
(\mathbf{d a y})\end{array}$ & $\begin{array}{c}\text { Root } \\
\text { Length } \\
(\mathbf{c m})\end{array}$ \\
\hline \multirow{2}{*}{$\begin{array}{c}\text { Irrigation } \\
\text { Methods }\end{array}$} & $\mathbf{S p}$ & 377.5 & 8.8 & 33.20 & 8.6 & 5 & 7 & $3.5 \mathrm{~b}$ \\
& $\mathbf{T i}$ & 404.4 & 7.7 & 31.35 & 8.5 & 5 & 7 & $3.5 \mathrm{~b}$ \\
& $\mathbf{F p}$ & 412.3 & 8.1 & 33.72 & 7.5 & 5 & 7 & $4.1 \mathrm{a}$ \\
\hline HSD & & $\mathrm{Ns}$ & $\mathrm{Ns}$ & $\mathrm{Ns}$ & $\mathrm{Ns}$ & $\mathrm{Ns}$ & $\mathrm{Ns}$ & $0.29 * *$ \\
\hline
\end{tabular}

HSD; Honesty Significant Difference, *; P <0.05, **; P <0.01, Ns; Not significant

Table 7. Overall appearance, shoot diameter, tiller number, leaf blade length, leaf blade width, and index values of different irrigation methods

\begin{tabular}{ccccccccc}
\hline Applications & $\begin{array}{c}\text { Overall } \\
\text { Appearance } \\
(\mathbf{1 - 9})\end{array}$ & $\begin{array}{c}\text { Shoot } \\
\text { Diameter } \\
(\mathbf{m m})\end{array}$ & $\begin{array}{c}\text { Tiller } \\
\text { Number } \\
(\text { number cm } \mathbf{~})\end{array}$ & $\begin{array}{c}\text { Leaf Blade } \\
\text { Length } \\
(\mathbf{c m})\end{array}$ & $\begin{array}{c}\text { Leaf Blade } \\
\text { Width } \\
(\mathbf{m m})\end{array}$ & $\begin{array}{c}\text { Index } \\
\text { Values }\end{array}$ \\
\hline \multirow{2}{*}{$\begin{array}{c}\text { Irrigation } \\
\text { Methods }\end{array}$} & $\mathbf{T p}$ & 9 & $0.51 \mathrm{a}$ & $833.2 \mathrm{a}$ & 6.3 & $1.06 \mathrm{a}$ & 59.6 \\
& $\mathbf{T p}$ & 9 & $0.53 \mathrm{a}$ & $722.1 \mathrm{~b}$ & 7.0 & $0.99 \mathrm{ab}$ & 70.8 \\
\hline HSD & 6 & $0.41 \mathrm{~b}$ & $555.5 \mathrm{c}$ & 6.6 & $0.90 \mathrm{~b}$ & 73.7 \\
\hline
\end{tabular}

HSD; Honesty Significant Difference, *; P <0.05, **; P <0.01, Ns; Not significant

The highest shoot diameter values were obtained from Sp and Ti applications $(0.51$ and $0.53 \mathrm{~mm}$, respectively) and they took place in the same statistical group (a). The lowest values $(0.41 \mathrm{~mm})$, on the other hand, were obtained from Fp applications $(\mathrm{P}<0.01)$. Whereas the highest $\left(833.2\right.$ number $\left.\mathrm{cm}^{2-1}\right)$ tiller number values were obtained from $\mathrm{Sp}$ applications, the lowest $\left(555.5\right.$ number $\left.^{2} \mathrm{~cm}^{-1}\right)$ values were obtained from Fp applications $(\mathrm{P}<0.01)$. The highest $(1.06 \mathrm{~mm})$ leaf blade width values were obtained from $S p$ applications, while the lowest $(0.90 \mathrm{~mm})$ values were obtained from Fp applications $(\mathrm{P}<0.05)$. 
The effects of different irrigation methods on overall appearance, leaf blade length and index values were not statistically significant (Table 7).

Karaşahin (2019), conducted to experiment to determine the effects of different irrigation methods (sprinkler, NFT, tidal, and capillary) on hydroponic barley grass, was obtained the highest green fodder yield from the sprinkler irrigation method, while he obtained the lowest green fodder yield from the capillary irrigation method. On the other hand, he obtained the highest dry matter rate and the lowest values of dry matter losses from the capillary irrigation method applications. He obtained the lowest dry matter rate and the highest dry matter losses values from the sprinkler irrigation method applications. He noted that whereas the highest root length values were obtained from NFT (Nutrient Film Technique) and tidal irrigation method applications, the lowest values were obtained from the applications of the capillary irrigation method. When these data and the current study results are compared, it is assumed that the similarities and differences stem from seed genera and species, as well as seed densities and growing periods.

\section{CONCLUSION}

According to research results, the highest fresh grass yields were obtained from $\mathrm{Co}, \mathrm{Wp}$ and $\mathrm{Tu}$ applications. The highest dry matter rate and dry grass yield values were obtained from Co growing medium applications. While the highest root length values were obtained from the applications of the Tu growing medium and Fp irrigation method, the highest shoot diameter values were obtained from the applications of the Wp growing medium, Pf substrate, Sp, and Ti irrigation method. The highest tiller number values were obtained from the applications of $\mathrm{Wp}$ and Tu growing media, Pf substrate, and $\mathrm{Sp}$ irrigation method. On the other hand, the highest leaf blade width values were obtained from the applications of Co and Wp growing media, Cf and Pf substrates, and Sp irrigation method.

It was observed that there was no statistical difference between the applications in terms of overall appearance values. When root length and tiller number values, which are among the important growth parameters in the soilless roll sod production, application conveniences, biodegradability, and production costs are considered together, "Tu" growing medium, "Cf" substrate and "Sp" irrigation method applications came to the fore. To be able to obtain more realistic recommendations on this issue, land applications should be included in future research.

\section{ACKNOWLEDGMENT}

The author is thankful for the support extended by Selçuk University Scientific Research Projects (BAP). This research consists of a part of the project numbered 17401185.

\section{Conflict of Interest}

I declare that there is no conflict of interest during the planning, execution and writing of the article.

\section{Author's Contibutions}

I hereby declare that the planning, execution and writing of the article was done by me as the sole author of the article.

\section{REFERENCES}

Albaho M, Bhat N, Abo-Rezq H, Thomas B, 2009. Effect of Three Different Substrates on Growth and Yield of Two Cultivars. Europe Journal of Science Resource, 28(2): 227-233.

Anton A, 1993. Fibrous Mat For Growing Plants. U.S. Patent 5224292 Date issued: 6 July. 
Beard JB, Green RL, 1994. The Role of Turf Grasses in Environmental Protection and Their Benefits to Humans. J. Env. Quality, 23: 452-460.

Brien O, Barker AV, 1995. Evaluation of Fresh and Year Old Solid Waste Composts for Production of Wild Flower and Grass Sods on Plastic Compost. Science and Utilization. 3(4): 69-77.

Bruce FS, 2000. Soilless Sod Use Tied to Economy, USGA Specs. Turfgrass Trends January, 9-12.

Carrow RN, 1995. Drought Resistance Aspects of Turfgrasses in The Creeping Bentgrass Cultivar Water Use and Rooting Responses. Crop southeast: Evapotranspiration and Crop Coefficients. 31: 1331-1334.

Decker HF, Decker JM, 1988. Lawn Care: A Handbook for Professionals. Prentice-Hall, Inc., Englewood Cliffs, N.J. 304 pp.

Decker HF, 2001. Producing Sods Over Plastic in Soilless Media. Horticultural Review, Vol. 27.

Dede ÖH, Özdemir, S. 2015. Comparison of Composted Biosolid Substrate for Containerized Turfgrass Production, Environmental Technology, 36 (13):1651-1656.

Farid FHM, Ahmad SS, Raub ABA, Shaari FM, 2016. Green "Breathing Facades" for Occupants' Improved Quality of Life. Procedia-Social and Behavioral Sciences 234: 173-184.

Gutierrez GAM, Altamirano GZ, Urrestarazu M, 2012. Maguey Bagasse Waste as Sustainable Substrate in Soilless Culture by Melon and Tomato Crop. Journal of Plant Nutrition, 35: 2135-2144.

Hensler KL, Baldwin BS, Goatley JM, 1998. Kenaf-based Fiber Mat as a Substrate for Establishing Soilless Sod. HortTechnology, 8 (2): 171-175.

Hussain RSR, 2017. Turf Grass Sod Production Utilizing Hydroponic Systems. Master Thesis. The College of Graduate Studies and the College of Food \& Agriculture, UAEU.

Johnson JH, Hochmuth GJ, Maynard DN, 2010. Soilless Culture of Greenhouse Vegetables. Institute of Food and Agricultural Sciences, 218: 19-22.

Karaşahin M, 2019. The Effects of Different Irrigation Method Treatments on Hydroponic Barley (Hordeum vulgare L. conv. distichon) Grass. 3. International Conference on Agriculture, Food, Veterinary and Pharmacy Sciences,16-18 April 2019, Trabzon, Turkey.

Karaşahin M, 2020. Topraksız Rulo Çim Üretimi ve Avantajları. HarmanTIME, 89: 94-96.

Mason J, 2003. Sustainable Agriculture. Landlinks Press, Australia. 205 pp.

MSU, 2006. MSU-Developed Sod Has Worldwide Appeal. http://extension.msstate.edu/news/featurestory/2006/msu-developed-sod-has worldwide-appeal (Reached October 5, 2018)

Munoz H, 2010. Hydroponics Home-Based Vegetable Production System Manual. Institute for Cooperation on Agriculture (IICA). Guyana. http://www.iica.int.

Pessarakli M, 2008. Hand Book of Turf Grass Management and Physiology. CRC Press, Tucson, Arizona, U.S.A. $690 \mathrm{pp}$.

Roberts BR, Decker HF, Ganahl LM, Yarmark E, 2001. Biosolid Residues as Soilless Media for Growing Creeping Bent Grass Sod. Hort. Technology. 11: (3) 451- 455.

Savvas D, Gianquinto G, Tuzel Y, Gruda N, 2013. Soilless Culture. FAO Plant Production and Protection Paper No. 217: Good Agricultural Practices for Greenhouse Vegetable Crops.

Sorochan JC, Rogers JN, 1995. Soilless Sod Production Using Ecomat. LT, 3-9.

Yeager TH, Fare D, Lea-Cox J, Ruter J, Bilderback TE, Gilliam CH, Niemiera AX, Warren L, Whitwell TE, Wright RD, Tilt KM, 2007. Best Management Practices: Guide for Producing Container Grown Plants. 2nd ed. Southern Nurserymen's Association, Maretta, GA. pp. 4-10. 